\title{
Foetal mortality in moderately zinc-deficient rats is strictly related to the process of parturition: effect of maternal essential fatty acid supplementation
}

\author{
BY S. C. CUNNANE* \\ Department of Nutritional Biochemistry, Rowett Research Institute, \\ Aberdeen, Scotland AB2 9SB
}

(Received 22 September 1981 - Accepted 28 October 1981)

1. Although disrupted parturition and high foetal losses have previously been reported in pregnant rats maintained on zinc-deficient diets this is the first report to differentiate between the effects of reduced $\mathrm{Zn}$ intake and the effects of reduced food intake on the outcome of pregnancy in the rat.

2. Rats maintained on a $0.5 \mathrm{mg} \mathrm{Zn} / \mathrm{kg}$ diet for the last $7 \mathrm{~d}$ of gestation or on a $5 \mathrm{mg} \mathrm{Zn} / \mathrm{kg}$ diet throughout gestation did not consume significantly less food than rats given 10 or $20 \mathrm{mg} \mathrm{Zn/kg} \mathrm{diets} \mathrm{except} \mathrm{during} \mathrm{the} \mathrm{last}$ $2 \mathrm{~d}$ of gestation. Pair-feeding of $\mathrm{Zn}$-adequate rats $(20 \mathrm{mg} / \mathrm{kg})$ to those given low- $\mathrm{Zn}$ diets for the last $2 \mathrm{~d}$ of gestation did not affect the outcome of pregnancy in these rats.

3. In the rats maintained throughout gestation on $5 \mathrm{mg} \mathrm{Zn} / \mathrm{kg}$ or on $0.5 \mathrm{mg} \mathrm{Zn} / \mathrm{kg}$ in the last $7 \mathrm{~d}$ of gestation, parturition onset and duration were not significantly altered. Foetal survival was very significantly reduced but only from day 22 onwards; before the onset of parturition, foetal survival was not significantly affected by $\mathrm{Zn}$ deficiency during gestation.

4. Subcutaneous injection of evening primrose (Oenothera biennis) oil into rats throughout gestation enhanced foetal and neonatal survival in rats given $5 \mathrm{mg} \mathrm{Zn} / \mathrm{kg}$ but reduced foetal survival in rats given $0.5 \mathrm{mg} \mathrm{Zn} / \mathrm{kg}$ in the last $7 \mathrm{~d}$ of gestation.

5. The results suggest three points: (1) subtotal $\mathrm{Zn}$ deficiency during gestation in the rat jeopardises foetal survival at parturition without affecting the onset or duration of parturition, (2) foetal death in rats maintained on $\mathrm{Zn}$-deficient diets occurs only in relation to parturition itself, (3) provided that $\mathrm{Zn}$ intake near term is at least $5 \mathrm{mg} / \mathrm{kg}$, supplemental essential fatty acids (evening primrose oil) will reduce foetal mortality during parturition and in the neonatal period.

Previous research on the effects of zinc deficiency on the process of parturition has shown that rats maintained on less than $2 \mathrm{mg} \mathrm{Zn} / \mathrm{kg}$ throughout gestation have prolonged and possibly delayed parturition and that foetal mortality is very significantly increased above normal (Apgar, 1968 a, b; O'Dell et al. 1977). These investigators have used the method of pair-feeding to try to compare more directly the $\mathrm{Zn}$-deficient and control groups because of the significantly reduced food intake in the former group. Unfortunately, there is evidence that reduced maternal food intake for a prolonged period during gestation has detrimental effects on foetal nutrition and survival (Rosso, 1977; Lederman \& Rosso, 1980). This point is, in fact, evident in one of the reports on $\mathrm{Zn}$ deficiency and parturition (Apgar, 1968a).

This study was therefore undertaken with the intention of determining whether subtotal $\mathrm{Zn}$ deficiency during gestation would affect either food intake or parturition. Less than $12 \mathrm{mg} \mathrm{Zn} / \mathrm{kg}$ intake reduces foetal and neonatal survival in rats (Williams et al. 1973) whereas $15 \mathrm{mg} \mathrm{Zn/kg}$, although not optimal, has been shown to be adequate for foetal survival and postnatal development (US National Research Council, 1979).

The groups in this study were therefore given 5,10 or $20 \mathrm{mg} \mathrm{Zn} / \mathrm{kg}$ diet. A fourth group was maintained on $10 \mathrm{mg} \mathrm{Zn} / \mathrm{kg}$ for the first $15 \mathrm{~d}$ of gestation and changed to $0.5 \mathrm{mg} \mathrm{Zn} / \mathrm{kg}$ for the remainder of gestation. This group was included to assess the effect of acute total $\mathrm{Zn}$ deprivation late in gestation.

* For reprints and correspondence: Department of Biochemistry, Nuffield Laboratories of Comparative Medicine, Institute of Zoology, Regent's Park, London, England NW1 4RY. 
Another aspect of interest was whether essential fatty acid supplementation would have any effect on foetal survival at parturition in $\mathrm{Zn}$-deficient rats. Evening primrose (Oenothera biennis) oil (EPO) supplementation ( $84 \%$ essential fatty acids) has previously been demonstrated to inhibit the onset of $\mathrm{Zn}$-deficiency symptoms in rats (Cunnane \& Horrobin, 1980; Huang et al. 1981) by making available prostaglandin precursors, the synthesis of which may be disrupted by $\mathrm{Zn}$ deficiency. EPO supplementation of $\mathrm{Zn}$-deficient rats during gestation was therefore also examined.

The results demonstrate that subtotal $\mathrm{Zn}$ deficiency during gestation adversely affects foetal survival at term independently of any effect of reduced food intake and support the observations that adequate $\mathrm{Zn}$ intake during gestation and particularly at term is critical to successful parturition. The reduced foetal mortality in rats given $5 \mathrm{mg} \mathrm{Zn} / \mathrm{kg}$ diet and supplemented with EPO supports the hypothesis that $\mathrm{Zn}$ deficiency significantly alters essential fatty acid metabolism.

\section{METHODS}

Second parity female Hooded Lister rats (Rowett Strain) were kept individually in polypropylene cages with stainless-steel gridded bottoms and tops and housed under 'barrier-maintained' conditions at all times. They were fed ad lib. on a semi-synthetic diet based on egg albumin, sucrose, arachis oil, inorganic salts, minerals and vitamins, a diet which has been fully described and validated elsewhere (Williams \& Mills, 1970). Doubledistilled water was also available $a d l i b$. Following successful mating with males of the same strain the pregnant rats were divided into four groups of five each: $20 \mathrm{mg} \mathrm{Zn} / \mathrm{kg}$ (control), $10 \mathrm{mg} \mathrm{Zn} / \mathrm{kg}, 5 \mathrm{mg} \mathrm{Zn} / \mathrm{kg}, 10 \mathrm{mg} \mathrm{Zn} / \mathrm{kg}$ for the first $15 \mathrm{~d}$ of gestation followed by $0.5 \mathrm{mg}$ $\mathrm{Zn} / \mathrm{kg}$ to term $(10 / 0.5 \mathrm{mg} \mathrm{Zn} / \mathrm{kg})$.

Additional groups of rats were maintained under identical conditions to that described previously in order to assess foetal mortality before and after normal parturition, effects of pair-feeding and the effects of supplementation with essential fatty acids (EPO). Three groups of female rats were mated and placed on diets containing 20,5 or $10 / 0.5 \mathrm{mg} \mathrm{Zn} / \mathrm{kg}$. Each group was subdivided into two with half receiving a daily subcutaneous injection of EPO ( $84 \%$ essential fatty acids) which was increased from $500 \mu \mathrm{l} / \mathrm{kg}$ per $\mathrm{d}$ in the first week of gestation to $600 \mu \mathrm{l} / \mathrm{kg}$ per d in the second week and to $700 \mu \mathrm{l} / \mathrm{kg}$ per d in the final week of gestation. The caging was as previously described and food and water were available ad $l i b$. In all experiments daily weight gain, food intake, length of gestation and parturition, weight loss at parturition and foetal weights and survival were measured. Subjective aspects of the effects of $\mathrm{Zn}$ deficiency at parturition such as the extent of haemorrhaging, skin lesions and alopecia were also noted. Statistical analysis between groups was done using Student's $t$ test.

\section{RESULTS}

Because the rats were housed under barrier-maintained conditions, dermal infection was minimal and the development of dermal lesions and oral incrustation rarely occurred. Alopecia was likewise an inconsistent feature of the $\mathrm{Zn}$-deficient rats. Hence the severity of $\mathrm{Zn}$ deficiency could not adequately be assessed by these factors.

\section{Effect of suboptimal $\mathrm{Zn}$ intake on maternal weight gain, organ weights and food intake during gestation}

A typical daily growth curve for the last $12 \mathrm{~d}$ of gestation and the first $2 \mathrm{~d}$ of lactation is shown in Fig. 1. The rats in the control group ( $20 \mathrm{mg} \mathrm{Zn} / \mathrm{kg}$ ) gained weight steadily to day 22 and lost $18.5 \%$ of their body-weight at term as the total products of conception. The rats given $10 \mathrm{mg} \mathrm{Zn} / \mathrm{kg}$ gained weight similarly but lost $21 \%$ of their final body-weight as 


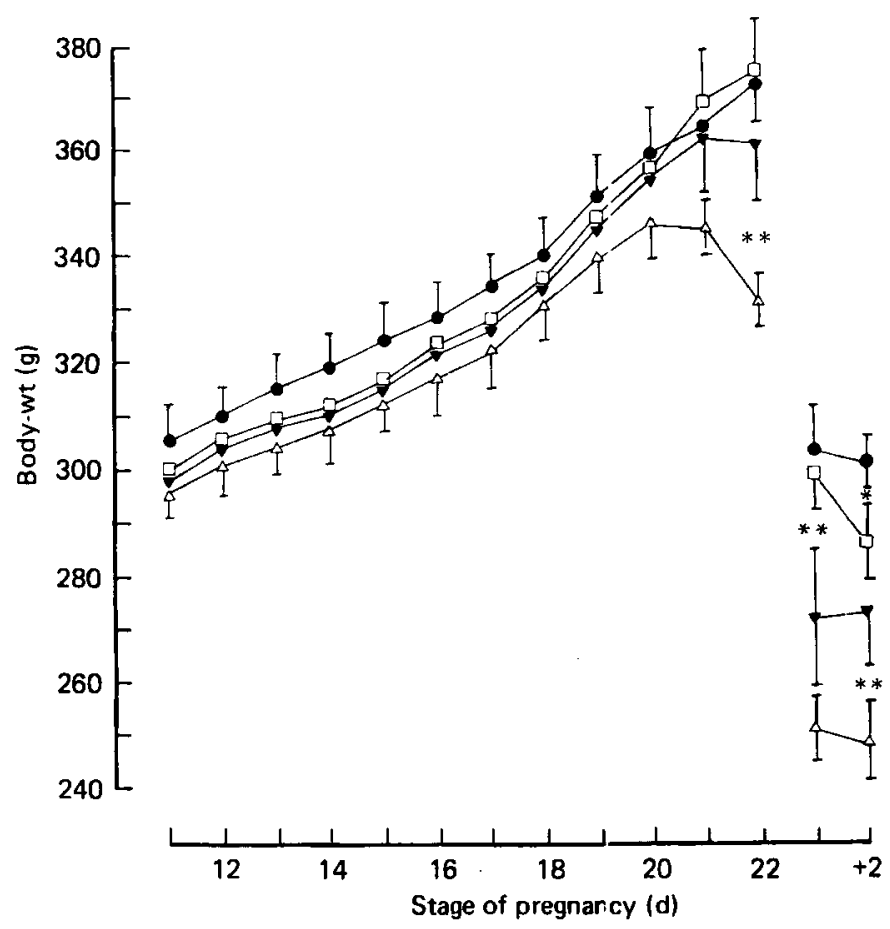

Fig. 1. The effect of diets containing various amounts of zinc on maternal weight gain during pregnancy and the first $2 \mathrm{~d}$ of lactation. Points represent mean values with their standard errors for five rats: (O-O), $20 \mathrm{mg} \mathrm{Zn} / \mathrm{kg}$; ( $\square-\square), 10 \mathrm{mg} \mathrm{Zn/kg;}(\nabla-\nabla), 5 \mathrm{mg} \mathrm{Zn} / \mathrm{kg} .(\triangle-\triangle), 10 \mathrm{mg} \mathrm{Zn} / \mathrm{kg}$ to day 15 of pregnancy followed by $0.5 \mathrm{mg} \mathrm{Zn} / \mathrm{kg}$ thereafter $(10 / 0.5 \mathrm{mg} \mathrm{Zn} / \mathrm{kg})$. Body-weight gain of the rats given $10 \mathrm{mg} \mathrm{Zn} / \mathrm{kg}$ did not differ from that of the rats given $20 \mathrm{mg} \mathrm{Zn} / \mathrm{kg}$ except on day 2 of lactation (day of pregnancy +2 ). Significance values compared to group fed $20 \mathrm{mg} \mathrm{Zn/kg:}{ }^{*}<0.05$, ${ }^{* *} P<0.01$.

the products of conception. The rats given $5 \mathrm{mg} \mathrm{Zn} / \mathrm{kg}$ had identical weight gains to those given 20 or $10 \mathrm{mg} \mathrm{Zn} / \mathrm{kg}$ up to day 21 but lost $25 \%$ of their final body-weight as the products of conception. The rats given $10 / 0.5 \mathrm{mg} \mathrm{Zn} / \mathrm{kg}$ gained weight normally to day 20 but lost weight thereafter to day 22 and lost $24 \%$ of their final body-weight on delivery. The increased weight loss of the latter two groups at parturition was significantly greater than in the $20 \mathrm{mg} \mathrm{Zn} / \mathrm{kg}$ diet $(P<0.05)$.

Values for liver, uterine, and peri-uterine fat weight: hody-weight were determined at the time of killing (day 22). Liver weight: body-weight and uterine weight: body-weight values were not significantly different between groups. The peri-uterine fat weight:body-weight was very significantly decreased only in the group given the $10 / 0.5 \mathrm{mg} \mathrm{Zn} / \mathrm{kg}$ diet.

Food intake in the control rats was consistently observed to increase to day 4 of gestation, remain constant at 19-21 g until day 12-14 and then decrease steadily thereafter to an intake of 10-14 $\mathrm{g}$ at term (Fig. 2). Food intake in the other three groups followed the same pattern as in the controls up to day 20 after which the intake of the rats in the groups given $5 \mathrm{mg}$ and $10 / 0.5 \mathrm{mg} \mathrm{Zn} / \mathrm{kg}$ diet dropped significantly below that of those given either the 10 or $20 \mathrm{mg} \mathrm{Zn} / \mathrm{kg}$ diet $(P<0.01)$. Over the 22 days of gestation the total food intake of the four groups did not vary significantly from each other. Thus it was only in the last $48 \mathrm{~h}$ of gestation that the rats on the low-Zn diets had significantly lower food intakes than the control group ( $20 \mathrm{mg} \mathrm{Zn} / \mathrm{kg}$ ). During the first two $\mathrm{d}$ of lactation the food intakes of the low- $\mathrm{Zn}$ rats were significantly below that of the groups given 10 or $20 \mathrm{mg} \mathrm{Zn} / \mathrm{kg}$ diet (Fig. 2). 




Fig. 2. Maternal food intake throughout pregnancy and including the first $2 \mathrm{~d}$ of lactation in rats given diets containing various levels of zinc. Points represent mean values with their standard errors for five rats:,$- 20 \mathrm{mg} \mathrm{Zn} / \mathrm{kg} ; \square-\square, 10 \mathrm{mg} \mathrm{Zn} / \mathrm{kg} ; \nabla-\nabla, 5 \mathrm{mg} \mathrm{Zn} / \mathrm{kg} ; \triangle-\triangle, 10 \mathrm{mg} \mathrm{Zn} / \mathrm{kg}$ for the first 15 days of pregnancy and $0.5 \mathrm{mg} \mathrm{Zn} / \mathrm{kg}$ thereafter $(10 / 0.5 \mathrm{mg} \mathrm{Zn} / \mathrm{kg})$. Significance values compared to group fed $20 \mathrm{mg} \mathrm{Zn/kg:} P<0.05$, ** $P<0.01$.

The trend to lower food intake in the low- $\mathrm{Zn}$ groups $(5 \mathrm{mg}$ and $10 / 0.5 \mathrm{mg} \mathrm{Zn} / \mathrm{kg}$ ) developed in the last $4 \mathrm{~d}$ of gestation but only became significant in the last $2 \mathrm{~d}$. The weight gain:food intake value, which is an indication of the efficiency of digestion and absorption was continually highest in the control group $(20 \mathrm{mg} \mathrm{Zn} / \mathrm{kg}$ ), and lowest in the group given $10 / 0.5 \mathrm{mg} \mathrm{Zn} / \mathrm{kg}$. In terms of weight gain $/ \mathrm{mg} \mathrm{Zn}$ intake, the group given the $5 \mathrm{mg} \mathrm{Zn} / \mathrm{kg}$ diet was significantly more efficient than those given either the 10 or $20 \mathrm{mg} \mathrm{Zn} / \mathrm{kg}$ diet, suggesting than an intake of $20 \mathrm{mg} \mathrm{Zn} / \mathrm{kg}$ is more than adequate for optimal growth during pregnancy in the rat. $\mathrm{Zn}$ excretion was not measured but on the basis of over-all weight gain $/ \mathrm{mg} \mathrm{Zn}$ intake, the efficiency of $\mathrm{Zn}$ absorption varied inversely with available $\mathrm{Zn}$, particularly in the last trimester.

\section{Effect of suboptimal $\mathrm{Zn}$ intake on events at parturition}

Parturition time was measured by checking every $15 \mathrm{~min}$ at the expected time of delivery for the emergence of the foetuses. Once parturition had started the progress of delivery was noted every $5 \mathrm{~min}$. Constant observation was not maintained because of the noticeable stress effect it had on the dams at parturition. Parturition times for the four groups are shown in Table 1. In general, parturition time bore no relation to foetal number in any of the groups. Although the trend was towards longer parturition time in the lowest-Zn group $(10 / 0 \cdot 5 \mathrm{mg} \mathrm{Zn} / \mathrm{kg}): 54 \pm 11 \mathrm{~min} v .72 \pm 13 \mathrm{~min}$, the effect was not significant.

Foetal number at birth was not significantly affected by $\mathrm{Zn}$ deficiency (Table 1). However, foetal weight and mortality varied directly and significantly with dietary $\mathrm{Zn}$ intake. Foetal 
Table 1. The effect of various levels of dietary zinc intake during gestation on parturition time, foetal characteristics at birth, and maternal fluid loss at parturition

(Mean values are shown with their standard errcrs for five rats/group)

\begin{tabular}{|c|c|c|c|c|c|c|c|c|}
\hline \multirow[t]{2}{*}{ Dietary $\mathrm{Zn}$ level $(\mathrm{mg} / \mathrm{kg}) \ldots$} & \multicolumn{2}{|c|}{20} & \multicolumn{2}{|c|}{10} & \multicolumn{2}{|c|}{5} & \multicolumn{2}{|c|}{$10 / 0 \cdot 5 \dagger$} \\
\hline & Mean & SE & Mean & SE & Mean & SE & Mean & SE \\
\hline Parturition time (min) & $53 \cdot 8$ & $11 \cdot 1$ & $73 \cdot 8$ & $11 \cdot 2$ & $63 \cdot 3$ & $15 \cdot 3$ & $72 \cdot 2$ & $12 \cdot 6$ \\
\hline Foetal no. & $11 \cdot 8$ & $1 \cdot 5$ & $10 \cdot 4$ & $1 \cdot 4$ & $10 \cdot 8$ & $1 \cdot 7$ & 9.9 & 0.9 \\
\hline Foetal wt (g) & $5 \cdot 24$ & $0 \cdot 35$ & $5 \cdot 16$ & 0.08 & $5 \cdot 10$ & $0 \cdot 12$ & $4 \cdot 23$ & $0 \cdot 58^{*}$ \\
\hline \multicolumn{9}{|l|}{ Foetal mortality $(\%)$} \\
\hline d 22 - gestation & 0.6 & 0.6 & 0.8 & 0.4 & $1 \cdot 4$ & $0 \cdot 5$ & $2 \cdot 1$ & $1 \cdot 0$ \\
\hline at birth & $4 \cdot 2$ & $5 \cdot 0$ & $12 \cdot 1$ & $9 \cdot 4$ & $48 \cdot 6$ & $7 \cdot 0^{*}$ & $65 \cdot 1$ & $13 \cdot 7^{* *}$ \\
\hline d 3 - lactation & $6 \cdot 4$ & $3 \cdot 2$ & 14.9 & $11 \cdot 6$ & $68 \cdot 1$ & $10 \cdot 6^{* * *}$ & $92 \cdot 4$ & $11 \cdot 2^{* * *}$ \\
\hline Maternal fluid loss $(\mathrm{g})_{+}^{+}$ & $6 \cdot 3$ & $1 \cdot 7$ & $8 \cdot 4$ & 0.9 & $19 \cdot 5$ & $3 \cdot 8 * *$ & $21 \cdot 1$ & $4 \cdot 2^{* *}$ \\
\hline
\end{tabular}

* $P<0.05,{ }^{* *} P<0.01, * * * P<0.001$.

$\dagger 10 \mathrm{mg} \mathrm{Zn} / \mathrm{kg}$ for the first $15 \mathrm{~d}$ of gestation and $0.5 \mathrm{mg} \mathrm{Zn} / \mathrm{kg}$ thereafter.

$\ddagger$ Maternal weight loss at parturition not attributable to foeto-placental weight as a percentage of the total weight loss at parturition.

weights at birth were $20 \%$ less in the $10 / 0.5 \mathrm{mg} \mathrm{Zn} / \mathrm{kg}$ group than in the other groups (Table 1). The percentage of foetuses still alive within $1 \mathrm{~h}$ of birth decreased dramatically with decreasing dietary $\mathrm{Zn}$ (Table 1 ). This trend continued post-natally due to maternal neglect. However, before the onset of parturition, i.e. up to and including day 22 of gestation, foetal mortality in all groups was negligible (Table 1). Thus, foetal mortality was associated strictly with the process of parturition itself. Occasional resorbtion sites were noted in the low-Zn groups but did not exceed the norrnal rate $(0.5-1.0 \%)$. In the low- $\mathrm{Zn}$ groups oedematous foetuses in the process of being resorbed were also occasionally present.

The comparison of foetal survival to $48 \mathrm{~h}$ post partum with maternal food intake between day 22 and 2 days post-partum is shown in Fig. 3. In spite of the trend towards increasing foetal survival with higher maternal food intake, there was no significant correlation between maternal food intake and foetal survival. This was due in part to the large variability in maternal food intake at term particularly in the low-Zn groups. Of the thirty-seven dams making up the values in Fig. 3, only five had foetal survival rates between $1-75 \%$. In the group given $10 / 0.5 \mathrm{mg} \mathrm{Zn} / \mathrm{kg}$, litters were either $90 \%$ live-born or $0 \%$ were live-born with no intermediate survival values occurring. Survival of the litters at birth would therefore appear to be an 'all-or-nothing' phenomenon, i.e. either survival is very low for the entire litter or more than $75 \%$ of the foetuses survive. This would suggest that each member of a given litter has an equal chance to survive maternal $\mathrm{Zn}$ deficiency and that preferential blood and nutrient supply to some foetuses does not ciccur.

The other feature of parturition to correlate directly with $\mathrm{Zn}$ deficiency during gestation was weight loss at parturition which was not accounted for by total foetal and placental weight. This difference is largely attributable to blood loss in the perinatal period. Dissection of the uterus on day 22 immediately before parturition invariably revealed moderate to extensive intrauterine haemorrhaging in the dams fed low- $\mathrm{Zn}$ diets, which invariably continued during parturition. Both the subjective extent of haemorrhaging in utero and the non-foeto-placental weight loss at parturition correlated with the extent of maternal $\mathrm{Zn}$ deficiency during gestation (Table 1). 


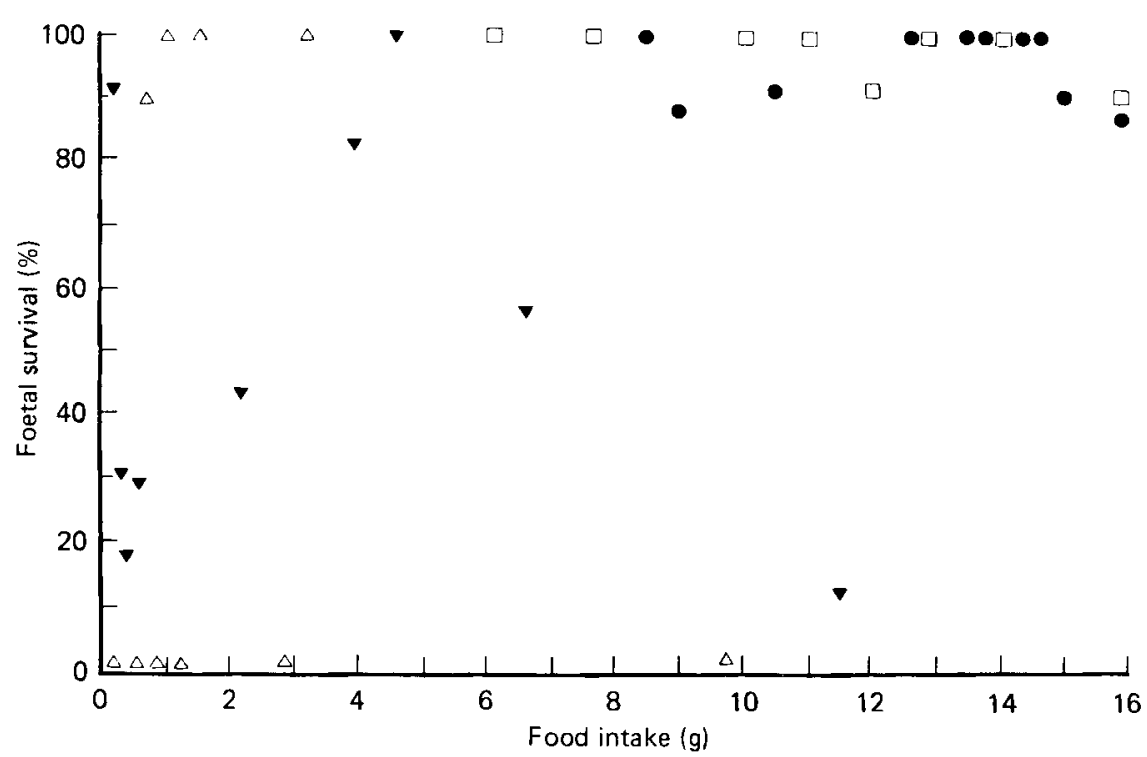

Fig. 3. Correlation between maternal food intake (mean of the intakes from day 22 of pregnancy to day 2 of lactation) and foetal survival (to day 2 of lactation) in rats given diets containing various levels of zinc. Points represent values for single rats: $-0,20 \mathrm{mg} \mathrm{Zn} / \mathrm{kg} ; \square-\square, 10 \mathrm{mg} \mathrm{Zn} / \mathrm{kg} ; \nabla-\nabla, 5 \mathrm{mg}$ $\mathrm{Zn} / \mathrm{kg} ; \triangle-\triangle, 10 \mathrm{mg} \mathrm{Zn} / \mathrm{kg}$ for the first 15 days of pregnancy followed by $0.5 \mathrm{mg} \mathrm{Zn} / \mathrm{kg}$ thereafter $(10 / 0 \cdot 5 \mathrm{mg} \mathrm{Zn} / \mathrm{kg})$.

\section{Effect of pair-feeding on foetal mortality at parturition}

The maternal food intake in previous experiments was always ad lib. for each group regardless of dietary $\mathrm{Zn}$ content. As shown in Fig. 2, food intake in the various groups did not vary significantly from control $(20 \mathrm{mg} \mathrm{Zn} / \mathrm{kg})$ up to day 20 of gestation, after which food intake in the low-Zn groups was significantly decreased. Two additional groups of pregnant rats, one given $20 \mathrm{mg} \mathrm{Zn} / \mathrm{kg}$ and the other given $5 \mathrm{mg} \mathrm{Zn} / \mathrm{kg}$ were pair-fed to another group given $10 / 0.5 \mathrm{mg} \mathrm{Zn} / \mathrm{kg}$ over the last $7 \mathrm{~d}$ of gestation. Foetal number, weight and survival to day 3 of lactation is shown in Table 2 for each of the groups. Foetal survival in rats pair-fed 20 and $5 \mathrm{mg} \mathrm{Zn} / \mathrm{kg}$ diets was not significantly different than in the ad lib. fed rats. This suggests that food intake in the $48 \mathrm{~h}$ period immediately preceeding parturition is not a limiting factor to foetal survival.

\section{Effect of essential fatty acid supplementation on foetal mortality at parturition}

EPO injection throughout gestation did not significantly affect daily weight gain or food intake in any of the groups. However, non-foeto-placental weight loss at parturition, which approximates maternal blood loss, was significantly less in the groups given 20 or $5 \mathrm{mg}$ $\mathrm{Zn} / \mathrm{kg}$ diet and injected with EPO than in the corresponding non-injected rats (Table 3). EPO had no effect on weight loss at parturition in the group given the $10 / 0.5 \mathrm{mg} \mathrm{Zn} / \mathrm{kg}$ diet. Litter size in the groups given the 20 and $5 \mathrm{mg} \mathrm{Zn/kg} \mathrm{diets} \mathrm{and} \mathrm{injected} \mathrm{with} \mathrm{EPO}$ was significantly lower than in the non-injected rats (Table 3). Foetal weights at birth or up to $3 \mathrm{~d}$ of age were not affected by EPO injection. However, survival of the neonates in the EPO-injected groups was significantly different than in the non-injected controls. There were no foetal deaths from birth up to $3 \mathrm{~d}$ of age in the group given $20 \mathrm{mg} \mathrm{Zn} / \mathrm{kg}$ diet and treated with EPO, whereas in the untreated group given the $20 \mathrm{mg} \mathrm{Zn} / \mathrm{kg}$ diet, mortality to $3 \mathrm{~d}$ of age was $10 \%$ (Table 3). In the group given the $5 \mathrm{mg} \mathrm{Zn} / \mathrm{kg}$ diet but not treated 
Table 2. Effect of pair-feeding rats maintained on 5 or $20 \mathrm{mg} \mathrm{Zn/kg} \mathrm{diets} \mathrm{over} \mathrm{the} \mathrm{last} 2 \mathrm{~d}$ of gestation to the daily intake of rats given $10 / 0.5 \mathrm{mg} \mathrm{Zn} / \mathrm{kg} \dagger$, on foetal number, weight and survival to day 3 of lactation

(Mean values are shown with their standard errors for five rats/group)

\begin{tabular}{|c|c|c|c|c|c|c|c|c|c|c|}
\hline \multirow{3}{*}{ Dietary $\mathrm{Zn}$ level $(\mathrm{mg} / \mathrm{kg}) \ldots$} & \multicolumn{6}{|c|}{ Ad lib.-fed } & \multicolumn{4}{|c|}{ Pair-fed } \\
\hline & \multicolumn{2}{|c|}{20} & \multicolumn{2}{|c|}{5} & \multicolumn{2}{|c|}{$10 / 0 \cdot 5 \dagger$} & \multicolumn{2}{|c|}{20} & \multicolumn{2}{|l|}{5} \\
\hline & Mean & $\mathrm{SE}$ & Mean & SE & Mean & SE & Mean & $\mathrm{SE}$ & Mean & SE \\
\hline Foetal no. per litter & $11 \cdot 3$ & $1 \cdot 1$ & $10 \cdot 9$ & 1.5 & $10 \cdot 3$ & 0.6 & $11 \cdot 7$ & $2 \cdot 1$ & $11 \cdot 8$ & $1 \cdot 3$ \\
\hline Foetal weight at birth $(\mathrm{g})$ & $5 \cdot 31$ & 0.27 & $5 \cdot 19$ & $0 \cdot 32$ & $4 \cdot 51$ & $0.41^{*}$ & $5 \cdot 11$ & $0 \cdot 5$ & $4 \cdot 85$ & 0.19 \\
\hline \multicolumn{11}{|l|}{ Foetal mortality $(\%)$} \\
\hline day 22 of gestation & 0.4 & 0.5 & 1.9 & $0 \cdot 7$ & 1.9 & $1 \cdot 5$ & $0 \cdot 7$ & $0 \cdot 5$ & 1.8 & $1 \cdot 3$ \\
\hline At birth & $3 \cdot 7$ & $3 \cdot 1$ & $41 \cdot 1$ & $8 \cdot 7^{* *}$ & $69 \cdot 4$ & $15 \cdot 2^{* *}$ & $5 \cdot 1$ & $3 \cdot 9+$ & $53 \cdot 7$ & $7 \cdot 2^{* * *} \|$ \\
\hline day 3 of lactation & 4.9 & $3 \cdot 0$ & $56 \cdot 4$ & $10 \cdot 3^{* *}$ & $88 \cdot 2$ & $16 \cdot 9 * *$ & 6.5 & $4 \cdot 1 f$ & $69 \cdot 0$ & $12 \cdot 5^{* * *}$ \\
\hline
\end{tabular}

* $P<0.05$ with respect to the group fed $20 \mathrm{mg} \mathrm{Zn} / \mathrm{kg}$, ad lib.

** $P<0.01$ with respect to the group fed $20 \mathrm{mg} \mathrm{Zn} / \mathrm{kg}$, ad lib.

*** $P<0.01$ with respect to the group fed $20 \mathrm{mg} \mathrm{Zn} / \mathrm{kg}$, pair-fed.

$\dagger 10 \mathrm{mg} \mathrm{Zn} / \mathrm{kg}$ for the first $15 \mathrm{~d}$ of gestation and $0.5 \mathrm{mg} \mathrm{Zn} / \mathrm{kg}$ thereafter.

$\ddagger$ Not significantly different with respect to the group fed $20 \mathrm{mg} \mathrm{Zn} / \mathrm{kg}$, ad lib.

|| Not significantly different with respect to the group fed $5 \mathrm{mg} \mathrm{Zn} / \mathrm{kg}$, ad lib.

Table 3. Effect of subcutaneous injection of evening primrose (Oenothera biennis) oil into dams given various levels of $\mathrm{Zn}$ during gestation, on maternal fluid loss, foetal weight and foetal mortality

(Mean values are shown with their standard errors for five rats/group)

\begin{tabular}{|c|c|c|c|c|c|c|c|c|c|c|c|c|}
\hline \multirow{3}{*}{ Dietary $\mathrm{Zn}$ level $(\mathrm{mg} / \mathrm{kg}) \ldots$} & \multicolumn{6}{|c|}{ Evening primrose oil-injected $\ddagger$} & \multicolumn{6}{|c|}{ Untreated } \\
\hline & \multicolumn{2}{|c|}{20} & \multicolumn{2}{|l|}{5} & \multicolumn{2}{|c|}{$10 / 0 \cdot 5 \dagger$} & \multicolumn{2}{|l|}{20} & \multicolumn{2}{|c|}{5} & \multicolumn{2}{|c|}{$10 / 0 \cdot 5 \dagger$} \\
\hline & Mean & SE & Mean & SE & Mean & SE & Mean & $\mathbf{S E}$ & Mean & SE & Mean & SE \\
\hline Maternal fluid loss (g)\| & $7 \cdot 3$ & $1 \cdot 0$ & 8.8 & $2 \cdot 9$ & $16 \cdot 7$ & $3 \cdot 4$ & $10 \cdot 0$ & $1 \cdot 2^{*}$ & $15 \cdot 6$ & $1 \cdot 2$ & $19 \cdot 6$ & $1 \cdot 6$ \\
\hline Foetal no. per litter & $9 \cdot 3$ & $1 \cdot 6$ & $7 \cdot 3$ & $1 \cdot 0$ & 8.7 & 1.5 & 11.5 & $1 \cdot 3$ & $10 \cdot 2$ & 1.6 & 8.9 & $1 \cdot 2$ \\
\hline \multicolumn{13}{|l|}{ Foetal mortality $(\%)$} \\
\hline At birth & 0 & - & $19 \cdot 5$ & $5 \cdot 7$ & $80 \cdot 1$ & $12.5 \S$ & 0 & - & $51 \cdot 5$ & $14 \cdot 3 * *$ & $86 \cdot 5$ & $9 \cdot 4$ \\
\hline day 3 of lactation & 0 & - & $24 \cdot 5$ & $7 \cdot 3$ & 100 & - & $10 \cdot 0$ & $5 \cdot 0^{*}$ & $69 \cdot 2$ & $15 \cdot 1^{* *}$ & 100 & - \\
\hline
\end{tabular}

- $P<0.05$ with respect to group given $20 \mathrm{mg} \mathrm{Zn} / \mathrm{kg}$, and injected with evening primrose oil.

** $P<0.01$ with respect to group given $5 \mathrm{mg} \mathrm{Zn/kg}$, and injected with evening primrose oil.

$+10 \mathrm{mg} \mathrm{Zn} / \mathrm{kg}$ for the first $15 \mathrm{~d}$ of gestation and $0.5 \mathrm{mg} \mathrm{Zn} / \mathrm{kg}$ thereafter.

$\ddagger 500 \mu \mathrm{l} / \mathrm{kg}$ per $\mathrm{d}$ increasing to $700 \mu \mathrm{l} / \mathrm{kg}$ per $\mathrm{d}$ at parturition.

\| Maternal weight loss at parturition not attributable to foeto-placental weight, as a percentage of the total weight loss at parturition.

$\S$ Maternal mortality was $80 \%$ in this group (4 out of 5 ).

with EPO, mortality at birth was $50 \%$ and increased to $70 \%$ at $3 \mathrm{~d}$ post-partum. In the group given the $5 \mathrm{mg} \mathrm{Zn} / \mathrm{kg}$ diet and treated with EPO, mortality both at birth and at $3 \mathrm{~d}$ of age was $40 \%$ less than that of the untreated group given the $5 \mathrm{mg} \mathrm{Zn} / \mathrm{kg}$ diet. EPO injection of the dams in the group given the $10 / 0.5 \mathrm{mg} \mathrm{Zn} / \mathrm{kg}$ diet did not affect foetal survival at birth but did cause significant maternal mortality shortly after parturition. 


\section{DISCUSSION}

This study was designed to investigate the effect of moderate, subtotal $\mathrm{Zn}$ deficiency during gestation on the outcome of pregnancy with a view to dissociating the effect of $\mathrm{Zn}$ deficiency and food intake on foetal survival at parturition. Thus the true effects of $\mathrm{Zn}$ deficiency, uncomplicated by reduced food intake during gestation, might then be assessed. The complication of reduced food intake during $\mathrm{Zn}$ deficiency is normally accepted as inevitable and pair-feeding of $\mathrm{Zn}$-adequate controls is considered the only alternative. However, in pregnancy studies, protein-energy depletion through decreased food intake is itself deleterious to foetal survival (Rosso, 1977; Lederman \& Rosso, 1980), but apparently not through decreased blood flow to the placenta (Rosso \& Kava, 1980). Hence a dietary $\mathrm{Zn}$ deficiency to a level sufficient to affect parturition but not to affect food intake significantly was sought. $\mathrm{Zn}$ intakes of either $5 \mathrm{mg} / \mathrm{kg}$ diet throughout gestation or $10 \mathrm{mg} / \mathrm{kg}$ diet for the first 2 weeks followed by $0.5 \mathrm{mg} / \mathrm{kg}$ diet for the remainder of gestation were found suitable for this purpose. Under these conditions the experimental results demonstrate that, although $\mathrm{Zn}$ is an inevitable determinant of food intake, moderate $\mathrm{Zn}$ deficiency does have clinically relevant effects on parturition which do not depend entirely on food intake at the end of gestation.

Under these conditions of $\mathrm{Zn}$ deficiency two important observations were made: (1) the duration of gestation and parturition were not significantly altered, (2) foetal mortality was almost exclusively limited to the period of imminent parturition. These observations suggest that in pregnancy in the rat, which is uncomplicated by reduced food intake, the major effect of $\mathrm{Zn}$ deficiency is to threaten foetal survival at parturition. Significant haemorrhaging both in utero and during parturition is also associated with the increase in foetal mortality.

The mechanism by which $\mathrm{Zn}$ deficiency affects foetal survival at parturition may involve prostaglandins in both the placenta and uterus. In vitro contractility of uterine strips from $\mathrm{Zn}$-deficient parturient rats has been shown to be significantly reduced (Cunnane, 1981 a) and may be associated with the decreased conversion of labelled arachidonic acid to prostaglandins $\mathrm{E}_{2}, \mathrm{~F}_{2 \alpha}$ and $\mathrm{I}_{2}$ in the uterus (Cunnane, $1981 \mathrm{~b}$ ). A significant reduction in placental perfusion at term (Cunnane et al. 1982) has recently been noted and may be related to an increase in placental conversion of labelled arachidonic acid to prostaglandins $E_{2}$, $\mathrm{F}_{2 \alpha}$ and $\mathrm{I}_{2}$ which also occurs in $\mathrm{Zn}$-deficient rats at term (Cunnane, 1981 $c$ ). Therefore altered uterine and placental prostaglandin synthesis from exogenous arachidonic acid suggests disrupted endogenous prostaglandin metabolism may contribute to uterine hypocontractility at a time when placental blood flow is also reduced. This in turn may be responsible for the high incidence of foetal mortality in Zn-deficient rats.

Supplementation with essential fatty acids (EPO treated groups) significantly reduced foetal mortality at parturition in rats maintained on $5 \mathrm{mg} \mathrm{Zn} / \mathrm{kg}$ diet throughout gestation. Although the EPO supplementation was given subcutaneously, its beneficial effect was similar to that seen clinically with intravenous infusion of a fat emulsion (Intralipid) in pregnancy (Elphick et al. 1978). They reported a possible beneficial effect of the linoleic acid (18:2 $n 6$ )-rich Intralipid in a patient at term whose baby had foetal growth retardation. Parenteral fat supplementation reportedly also increases uterine contractions, particularly near parturition (Heller, 1972). Since uterine hypocontractility has been demonstrated in $\mathrm{Zn}$-deficient rats at term (Cunnane, $1981 \mathrm{a}$ ), a reversal of this situation may be an additional effect of EPO injection.

The effectiveness of EPO in inhibiting the onset of $\mathrm{Zn}$ deficiency symptoms has been suggested to be due to the presence of the essential fatty acid $\gamma$-linolenic acid $(18: 3 n 6)$ (Cunnane \& Horrobin, 1980; Huang et al. 1981). $\gamma$-linolenic acid is synthesized from the 
parent essential fatty acid linoleic acid by the $\Delta^{6}$ desaturase enzyme, the activity of which has been shown to be increased in the uterus in $\mathrm{Zn}$-deficient rats at term (Cunnane \& Wahle, 1981). Essential fatty acid supplementation, however, will tend to normalize such a change (Holman, 1981). Thus, in animals with marginal $\mathrm{Zn}$ intake (i.e. $5 \mathrm{mg} \mathrm{Zn} / \mathrm{kg}$ diet), EPO supplementation may counter the effect of $\mathrm{Zn}$ deficiency in animals by making ' $\mathrm{l}$ ' series prostaglandin precursors directly available and by reducing the increased activity of the $\Delta^{\boldsymbol{\theta}}$ desaturase, hence decreasing arachidonic acid synthesis from linoleic acid.

It would appear that the effects of essential fatty acid supplementation in $\mathrm{Zn}$-deficient rats depend on the amount of $\mathrm{Zn}$ in the diet. Thus, although it is effective at a $\mathrm{Zn}$ intake of as low as $2 \mathrm{mg} / \mathrm{kg}$ diet (Cunnane \& Horrobin, 1980), in the rats in this experiment which were maintained on $0.5 \mathrm{mg} \mathrm{Zn} / \mathrm{kg}$ diet in the last trimester of pregnancy, EPO supplementation did not affect foetal survival and actually increased maternal mortality at parturition. High maternal mortality near parturition has also been shown to occur in vitamin E-deficient pregnant rats given high amounts of peroxidized fats including linoleic acid (Stamler, 1959). Death was related to the development of oedema and thrombi in the kidneys, adrenals and spleen and occurred in the terminal stage of pregnancy (day 22). It was also associated with eclampsia-like convulsions. In view of the fact that in the pregnant rats in the present experiments which were maintained on $0.5 \mathrm{mg} \mathrm{Zn} / \mathrm{kg}$ diet during the last $7 \mathrm{~d}$ of pregnancy, maternal death occurred only on day 22 in close association with parturition, and only in those rats also given EPO ( $72 \%$ linoleic acid), suggests that diets deficient in vitamin $\mathrm{E}$ or $\mathrm{Zn}$ and containing high amounts of polyunsaturated fatty acids have similar detrimental effects on the outcome of pregnancy. This view is further supported by the fact that like vitamin $\mathrm{E}, \mathrm{Zn}$ may have a significant function in the control of lipid peroxidation (Bettger \& O'Dell, 1981). Although the results are as yet incomplete, it is not unreasonable to suggest that extreme $\mathrm{Zn}$ deficiency may contribute to the development of eclampsia-like syndromes in the rat.

Considering the fact that in $\mathrm{Zn}$-deficient pregnant rats: (1) pair-feeding of $\mathrm{Zn}$-adequate pregnant rats to very low food intakes in the last $2 \mathrm{~d}$ of gestation had no significant effects on foetal growth or survival, (2) peri-uterine fat was very significantly decreased in relation to body-weight, (3) $\mathrm{Zn}$ is closely related to essential fatty acid metabolism, suggests that foetal lipid intake near term may be more of a limiting factor to foetal growth and survival than protein intake. The present results, showing a reduction of foetal mortality in EPO-supplemented pregnant rats, further supports this possibility.

In conclusion, it is apparent that subtotal $\mathrm{Zn}$ deficiency during gestation in the rat not only has pathophysiological effects on the foetus which are of clinical relevance but also can be dissociated from effects complicated by food intake reduction. The fact that a $\mathrm{Zn}$ intake at $25 \%$ of the adequate level was sufficient to increase significantly foetal mortality makes $\mathrm{Zn}$ deficiency in human high-risk pregnancies which are associated with poor nutrition much more of a reality than has previously been suggested. This is true in spite of the fact that no adequate measure of human $\mathrm{Zn}$ status in health or disease is yet available.

S.C.C. is very grateful to the Lalor Foundation of Wilmington, Delaware, USA for a post-doctoral fellowship and grant. Excellent dietary management of the rats was provided by Mrs A. Watt. The EPO was kindly supplied by Efamol Limited, London.

\section{REFERENCES}

Apgar, J. (1968a). Am. J. Physiol. 215, 160.

Apgar, J. (1968b). Am. J. Physiol. 215, 1478.

Bettger, W. J. \& O'Dell, B. L. (1981). Life Sci. 28, 1425.

Cunnane, S. C. (1981 a). Proc. Nutr. Soc. 40, 80 A. 
Cunnane, S. C. $(1981$ b). Proc. Nutr. Soc. 40, 78 A.

Cunnane, S. C. (1981 c). Proc. Nutr. Soc. 40, 114 A.

Cunnane, S. C. \& Horrobin, D. F. (1980). Proc. Soc. exp. Biol. Med. 164, 583.

Cunnane, S. C., Majid, E., Senior, J. \& Mills, C. F. (1982). Proc. Nutr. Soc. (In the Press).

Cunnane, S. C. \& Wahle, K. W. J. (1981). XIIth int. Congr. Nutr., San Diego.

Elphick, M. C., Filshie, G. M. \& Hull, D. (1978). Br. J. Obstet. Gynaec. 85, 610.

Heller, L. (1972). Parenteral Nutrition. Edinburgh: Churchill Livingstone.

Holman, R. T. (1981). Prog. Clin. Biol. Med. (In the Press).

Horrobin, D. F. \& Cunnane, S. C. (1980). Med. Hypotheses 6, 277.

Huang, Y. S., Cunnane, S. C., Horrobin, D. F. \& Davignon, J. (1982). Athersclerosis (In the Press). Lederman, S. A. \& Rosso, P. (1980). Growth 44, 77.

O'Dell, B. L., Reynolds, G. \& Reeves P. G. (1977). J. Nutr. 107, 1222.

Rosso, P. (1977). Fedn Proc. Fedn Am. Socs exp. Biol. 39, 250.

Rosso, P. \& Kava, R. (1980). J. Nutr. 110, 2350.

Stamler, F. W. (1959). Am. J. Path. 35, 1207.

US National Research Council (1979). Zinc. Baltimore: University Park Press.

Williams, R. B., Demertzis, P. \& Mills, C. F. (1973). Proc. Nutr. Soc. 32, 3 A.

Williams, R. B. \& Mills, C. F. (1970). Br. J. Nutr. 24, 989. 